\title{
SYARIAH GOVERNANCE PADA PERBANKAN SYARIAH
}

\author{
Joko Hadi Purnomo \\ Sekolah Tinggi IImu A gama Islam A I Hikmah Tuban \\ e-mail: joko.hpurnomo@gmail.com
}

\begin{abstract}
A bstract: Shariah governance is concatenation of two concepts, these are the concept of good corporate governance and shariah compliance. The governance of banks applies the principle of transparency, accountability, responsibility, professionalism and fairness whereas shariah compliance is the duty of Islamic bank to meet compliance with Islamic principles. The operation of Islamic banks must strictly adhere to the provisions of shariah. The application of shariah governance is the implementation of good corporate governance principles and shariah compliance. The implementation of shariah governance in Islamic banks relies on surveillance covering all research activities, observation and measurement on the course of operations, both internally and externally. B ased on the above background, author makes formulations of the problem; (a) how is the implementation of Shariah governance in Islamic bank?; (b) How is the supervision of the application of Shariah governance in Islamic bank?. The purpose of this paper is to know the implementation of Shariah governance in Islamic banks and to know the supervision of the implementation of Shari'a governance in Islamic bank. The implementation of GCG in Islamic banking creates transparency to prevent fraud, conduct accountability with the system that controls the relationship between the organs of company, do responsibility, keep independence, and keep in touch with fairness. The application of sharia compliance at Islamic banks without riba in bank transactions, no vagueness (gharar) in bank transactions, there is no gambling (maisir) in bank transactions. Bank conducts business on the basis of allowed (halal) profits. Banks manage zakat, sadaqah, and infaq according to the shariah provisions. The implementation of sharia governance in Islamic banks relies on surveillance covering all research activities, observation and measurement on the course of the operation by using elements of the AGM, Board of Commissioner, B oard of A uditor, Shariah Supervisory Board (DPS), Director of Compliance, Internal A udit, Internal Shari'a Reviewers of SKAI and external monitoring system consists of elements of the Financial Services Authority (OJK), Public A ccountant, National Sharia Council (DSN) and Stakeholders.
\end{abstract}

Keywords: Corporate, syariah, Governance

\section{Pendahuluan}

Perbankan syariah memiliki peran strategis dalam meningkatkan kesejahteraan umat, baik melalui proses intermediasi kegiatan penghimpunan maupun penyaluran dana serta penyediaan jasa keuangan lainnya yang berlandaskan pada prinsip-prinsip syariah. Bank syariah merupakan lembaga keuangan yang beroperasi berdasarkan prinsip syariah dan menghilangkan sistem riba. Peranan perbankan syariah dalam aktivitasnya tidak jauh 
berbeda dengan perbankan konvensional. Perbedaan antara keduanya terletak pada prinsipprinsip dalam transaksi keuangan. Salah satu prinsip dalam perbankan syariah adalah penerapan bagi hasil yang sesuai dengan kaidah ajaran Islam. Prinsip ini tidak berlaku di perbankan konvensional yang menerapkan sistem bunga.

Berdasarkan tabel 1 di bawah, diketahui bahwa dari tahun ke tahun perkembangan jumlah kantor Bank Umum Syariah (BUS), Unit Usaha Syariah (UUS) dan Bank Pembiayaan Rakyat Syariah (BPRS) mengalami kenaikan. Pada periode 2008 hingga 2014 jumlah BUS bertambah sebanyak 7 BUS dan jumlah kantor meningkat sebanyak 1.570 kantor. Sedangkan UUS mengalami penurunan sebanyak 5 UUS dikarenakan beberapa UUS telah berdiri sendiri menjadi BUS, namun UUS yang masih bertahan tetap mengalami peningkatan kantor sebanyak 79 kantor. Dan untuk BPRS mengalami peningkatan sebanyak 32 BPRS dan jumlah kantor meningkat sebanyak 237 kantor.

\section{Tabel 1}

Perkembangan J umlah dan Kantor Perbankan Syariah Nasional Tahun 2008-2014

\begin{tabular}{|l|r|r|r|r|r|r|r|}
\hline \multirow{2}{*}{\multicolumn{1}{c|}{ Jumlah Perbankan Syariah }} & \multicolumn{7}{|c|}{ Tahun } \\
\cline { 2 - 8 } & $\mathbf{2 0 0 8}$ & $\mathbf{2 0 0 9}$ & $\mathbf{2 0 1 0}$ & $\mathbf{2 0 1 1}$ & $\mathbf{2 0 1 2}$ & $\mathbf{2 0 1 3}$ & $\mathbf{2 0 1 4}$ \\
\hline B ank U mum Syariah & 5 & 6 & 11 & 11 & 11 & 11 & 12 \\
\hline J umlah K antor & 581 & 711 & 1.401 & 1.401 & 1.745 & 1.998 & 2.151 \\
\hline Unit U saha Syariah & 27 & 25 & 24 & 24 & 24 & 23 & 22 \\
\hline J umlah K antor & 241 & 287 & 336 & 336 & 517 & 590 & 320 \\
\hline B ank Pembiayaan Rakyat Syariah & 131 & 138 & 155 & 155 & 158 & 163 & 165 \\
\hline J umlah K antor & 247 & 260 & 364 & 364 & 401 & 402 & 439 \\
\hline Total K antor & 1.069 & 1.258 & 2.101 & 2.101 & 2.663 & 2.990 & 2.910 \\
\hline
\end{tabular}

Sumber : Statistik Perbankan Syariah Otoritas J asa K euangan (OJK) T ahun 2014

Indikasi perkembangan perbankan syariah diketahui pula dari perkembangan aset dan dana pihak ketiga yang dihimpun. Berdasarkan data pada tabel 2 di bawah, perbankan syariah mencapai total aset sebesar Rp 272.343 milyar. Pembiayaan telah mencapai Rp. 199.330 milyar dan penghimpunan dana menjadi Rp. 217.858 milyar.

Penghimpunan dana terbesar dalam bentuk deposito yaitu Rp.135.629 milyar diikuti oleh tabungan Rp. 63.581 milyar dan giro sebesar Rp.18.649 milyar. Penyalur dana masih didominasi piutang murabahah sebesar Rp.14.354 milyar, diikuti pembiayaan musyarakah sebesar Rp. 49.387 milyar dan pembiayaan murabahah sebesar Rp. 117.371 milyar, dan piutang qardh sebesar Rp. 5.965 milyar.

T abel 2

Perkembangan A set dan Dana Pihak Ketiga Perbankan Syariah T ahun 2008-2014 (dalam milyar R upiah)

\begin{tabular}{|l|r|r|r|r|r|r|r|}
\hline Tahun & $\mathbf{2 0 0 8}$ & $\mathbf{2 0 0 9}$ & $\mathbf{2 0 1 0}$ & $\mathbf{2 0 1 1}$ & $\mathbf{2 0 1 2}$ & $\mathbf{2 0 1 3}$ & $\mathbf{2 0 1 4}$ \\
\hline Total A ktiva & 49.555 & 66.090 & 97.519 & 145.467 & 195.018 & 242.276 & 272.343 \\
\hline Pembiayaan & 38.195 & 46.886 & 68.181 & 102.655 & 147.505 & 184.122 & 199.330 \\
\hline Dana Pihak K etiga & 36.852 & 52.271 & 76.036 & 115.415 & 147.512 & 183.534 & 217.858 \\
\hline
\end{tabular}


Perkembangan yang menunjukkan trend kenaikan tidak berarti pendirian perbankan syariah tidak memperhatikan hal-hal prinsip seperti pelaksanaan syariah governance. Perbankan syariah merupakan bisnis yang berlandaskan nilai-nilai dan prinsip Islam, sehingga perbankan syariah berbeda dengan bisnis perbankan konvensional. Perbankan syariah terikat kepada kewajiban untuk patuh terhadap prinsip dan norma syariah. Secara normatif, tentu saja kepatuhan terhadap syariah ini diyakini akan membawa kemaslahatan bagi semua pihak dalam muamalah. Namun, harus dimaklumi tidak selamanya simbol agama yang melekat pada perbankan syariah tidak akan selalu menjamin sebuah perbankan syariah bersih dan bebas dari perilaku korupsi dalam memenuhi kewajiban patuh terhadap ketentuan syariah itu sendiri. A tas dasar itulah, maka diperlukan adanya suatu mekanisme penilaian tentang kepatuhan bank syariah terhadap prinsip dan norma syariah melalui syariah governance sebagai bagian dari corporate governance bagi praktik bisnis syariah. Tentu saja tidak berhenti hanya sebatas menilai saja, pengkondisian berbagai sektor pendukung aktivitas perbankan syariah kepada terwujudnya syariah governance juga menjadi prioritas untuk dilaksanakan. ${ }^{1}$

Implementasi syariah governance di perbankan syariah dalam rangka memastikan operasional bank syariah tetap sesuai koridor syariah, menerapkan syariah compliance (memenuhi kepatuhan pada prinsip syariah). Penerapan syariah governance menghadapi berbagai tantangan di era sekarang, di mana derasnya arus informasi dan semakin terbukanya ekosistem perbankan syariah dengan perkembangan teknologi informasi yang cepat. Tantangan tersebut di antaranya mengenai implementasi syariah governance, pengawasan penerapan syariah governance, regulasi-regulasi yang menjamin pelaksanaan syariah governance, mekanisme kepatuhan operasional perbankan syariah terhadap regulasi, dan penggunaan instrumen penilaian pelaksanaan syariah governance.

\section{Pembahasan}

Syariah governance merupkan penggabungan dari dua konsep; konsep good corporate governance dan syariah compliance ${ }^{2}$, yaitu tata kelola bank yang menerapkan prinsip transparansi, akuntabilitas, pertanggungjawaban, profesional, dan kewajaran. Sedangkan shariah compliance adalah kewajiban bank syariah untuk memenuhi kepatuhan pada prinsip syariah. O perasional bank syariah harus benar-benar mengikuti ketentuan-ketentuan syariah.

\section{G ood C orporate G overnance (G C G )}

Good Corporate Governance (GCG) adalah tata kelola perusahaan yang baik (good corporate governance) merupakan struktur yang oleh stakeholder, pemegang saham, komisaris dan manajer menyusun tujuan perusahaan dan sarana untuk mencapai tujuan tersebut dan mengawasi kinerja. $^{3}$ Sedangkan Forum Corporate Governance in Indonesia

\footnotetext{
1 Dwi Saputro Alumni, "Penguatan Sharia Governance Melalui Reformasi Akuntansi", disampaikan dalam Simposium Nasional XIII Universitas Jendral Soedirman Purwokerto tahun 2010, 2

2 Akhmad Faozan, dalam Asy-Syir'ah, Jurnal Ilmu Syariah dan Hukum, Vol. 49, No. 1, Desember 2014, 341

${ }^{3}$ Moh. Wahyudi Zarkasi, Good Corporate Governance pada Badan Usaha Manufaktur, Perbankan dan Jasa Keuangan Lainnya (Bandung: CV. Alfabeta, 2008), 35
} 
(FCGI) mendefinisikannya sebagai seperangkat peraturan yang mengatur hubungan antara pemegang saham, pengurus/pengelola perusahaan, pihak kreditur, pemerintah, karyawan serta pemegang saham, kepentingan internal dan eksternal lainnya yang berkaitan dengan hak-hak dan kewajiban mereka atau dengan kata lain yaitu sistem yang mengatur dan mengendalikan perusahaan. Tujuan corporate governance ialah untuk menciptakan nilai tambah bagi semua pihak yang berkepentingan (stakeholders).

Corporate governance sebagai mekanisme administratif yang mengatur hubunganhubungan antara manajemen perusahaan, komisaris, di reksi, pemegang saham dan kelompokkelompok kepentingan (stakeholders) yang lain. Hubungan-hubungan ini dimanifestasikan dalam bentuk berbagai aturan permainan dan sistem insentif sebagai framework yang diperlukan untuk menentukan tujuan-tujuan perusahaan dan cara-cara pencapaian tujuantujuan serta pemantauan kinerja yang dihasilkan. ${ }^{4}$

Secara definitif, corporate governance merupakan proses dan struktur yang digunakan untuk mengarahkan dan mengelola bisnis dan urusan-urusan perusahaan dalam rangka meningkatkan kemakmuran bisnis dan akuntabilitas perusahaan dengan tujuan utama mewujudkan nilai pemegang saham dalam jangka panjang dengan tetap memperhatikan kepentingan stakeholders yang lain. Tata kelola perusahaan yang baik (good corporate governance) merupakan struktur yang oleh stakeholder, pemegang saham, komisaris, dan manajer menyusun tujuan perusahaan dan sarana untuk mencapai tujuan tersebut dan mengawasi kinerja. ${ }^{5}$

GCG pada dasarnya merupakan suatu sistem (input, proses, output) dan seperangkat peraturan yang mengatur hubungan antara berbagai pihak yang berkepentingan (stakeholders), terutama dalam arti sempit yaitu hubungan antara pemegang saham, dewan komisaris, dan dewan direksi demi tercapainya tujuan perusahaan. GCG dimaksudkan untuk mengatur hubungan-hubungan ini dan mencegah terjadinya kesalahan-kesalahan signifikan dalam strategi perusahaan dan untuk memastikan bahwa kesalahan-kesalahan yang terjadi dapat diperbaiki dengan segera. ${ }^{6}$

Corporate governance adalah suatu proses dan struktur yang digunakan oleh organ BUMN untuk meningkatkan keberhasilan usaha dan akuntabilitas perusahaan guna mewujudkan nilai pemegang saham dalam jangka panjang dengan tetap memperhatikan kepentingan stakeholder lainnya, berlandaskan peraturan perundangan dan nilai-nilai etika. ${ }^{7}$ Terwujudnya Good Corporate Governance (GCG) dalam organisasi merupakan salah satu penjabaran dari terlaksananya mekanisme pengelolaan risiko organisasi melalui sistem yang dirancang dalam rangka mengidentifikasi dan menganalisis risiko yang mungkin terjadi, baik yang timbul karena faktor eksternal maupun faktor internal yang berpotensi menghambat pencapaian tujuan.

\footnotetext{
${ }^{4}$ Wahjudi Prakarsa, "Corporate Governance : Suatu Keniscayaan” dalam Jurnal Reformasi Ekonomi, Volume I, Nomor 2 (Oktober-Desember 2000), 20

5 Organization for economic coperation and development (OECD), "The OECD principles of corporate governance", diakses pada tanggal 28 Agustus 2014 melalui http://www.oecd.org

6 "Jurnal Penerapan Prinsip-Prinsip Good Corporate Governance (GCG) Pada Dunia Perbankan" dalam http://lismaaja.blogspot.com/2011/12/jurnal-penerapan-prinsip-prinsip-good.html, (12 Maret 2016).

${ }^{7}$ Keputusan Menteri Badan Usaha Milik Negara No.Kep 117 / M-MBU / 2002
} 
Dengan berbagai pengertian tersebut, dapat ditarik kesimpulan bahwa good corporate governance (GCG) pada dasarnya merupakan suatu sistem (input, proses, output) dan seperangkat peraturan yang mengatur hubungan antara berbagai pihak yang berkepentingan (stakeholders) terutama dalam arti sempit hubungan antara pemegang saham, dewan komisaris, dan dewan direksi demi tercapainya tujuan perusahaan. GCG dimasukkan untuk mengatur hubungan-hubungan ini dan mencegah terjadinya kesalahan- kesalahan signifikan dalam strategi perusahaan dan untuk memastikan bahwa kesalahan-kesalahan yang terjadi dapat diperbaiki dengan segera.

\section{Penerapan G C G pada Perbankan Syariah}

Pengertian GCG di atas mencakup 5 (lima) prinsip yang harus dipatuhi yaitu keterbukaan (transparancy), akuntabilitas (accountability), tanggung jawab (responsibility), independensi (independency), dan kewajaran (fairness).

a. Keterbukaan (Transparancy)

B ank harus mengungkapkan informasi secara tepat waktu, memadai, jelas, akurat, dan dapat diperbandingkan serta mudah diakses oleh stakeholders sesuai dengan haknya. Informasi yang harus diungkapkan meliputi dan tidak terbatas pada hal-hal yang bertalian dengan visi, misi, sasaran usaha dan strategi perusahaan, kondisi keuangan, susunan dan kompensasi pengurus, pemegang saham pengendali, cross shareholding, pejabat eksklusif, pengelola risiko (risk management), sistem pengawas dan pengendalian internal, status kepatuhan, sistem dan pelaksanaan GCG serta kejadian penting yang dapat mempengaruhi kondisi bank.

Prinsip keterbukaan yang dianut oleh bank tidak mengurangi kewajiban untuk memenuhi ketentuan rahasia bank sesuai dengan peraturan perundang-undangan yang berlaku, rahasia jabatan, dan hak-hak pribadi. Kebijakan bank harus tertulis dan dikomunikasikan kepada pihak yang berkepentingan (stakeholders) dan yang berhak memperoleh informasi tentang kebijakan tersebut.

Transparancy berhubungan dengan kualitas informasi yang disampaikan perusahaan. Kepercayaan investor akan sangat tergantung dengan kualitas informasi yang disampaikan perusahaan. Oleh karena itu perusahaan dituntut untuk menyediakan informasi yang jelas, akurat, tepat waktu dan dapat dibandingkan dengan indikatorindikator yang sama. Penyampaian informasi kepada publik secara terbuka, benar, kredibel, dan tepat waktu akan memudahkan untuk menilai kinerja dan risiko yang dihadapi perusahaan serta mencegah terjadinya fraud. ${ }^{8}$

b. A kuntabilitas (A ccountability)

Bank harus menetapkan tanggung jawab yang jelas dari masing-masing organ organisasi yang selaras dengan visi, misi, sasaran usaha dan strategi perusahaan. Bank harus menyakini bahwa semua organ organisasi bank mempunyai kompetensi sesuai dengan tanggung jawabnya dan memahami perannya dalam pelaksanaan GCG. Bank

\footnotetext{
${ }^{8}$ Bismar Nasution, "Prinsip Keterbukaan dalam Good Corporate Governance", dalam Jurnal Hukum Bisnis, Volume XXII, Nomor 6 (2003), 5
} 
harus memastikan terdapatnya check and balance system dalam pengelolaan bank. Bank harus memiliki ukuran kinerja dari semua jajaran bank berdasarkan ukuran-ukuran yang disepakati konsisten dengan nilai perusahaan (corporate values), sasaran usaha dan strategi bank serta memiliki rewards dan punishment system. A kuntabilitas berhubungan dengan adanya sistem yang mengendalikan hubungan antara organ-organ yang ada di perusahaan. A kuntabilitas diperlukan sebagai salah satu solusi mengatasi agency problem yang timbul antara pemegang saham dan direksi serta pengendaliannya oleh komisaris.

c. Tanggung Jawab (R esponsibility)

Untuk menjaga kelangsungan usahanya, bank harus berpegang pada prinsip kehatihatian (prudential banking practices) dan menjamin dilaksanakannya ketentuan yang berlaku. Bank harus bertindak sebagai good corporate citizen (perusahaan yang baik) termasuk peduli terhadap lingkungan dan melaksanakan tanggung jawab sosial.

d. Independensi (Independency)

Bank harus menghindari terjadinya dominasi yang tidak wajar oleh stakeholder manapun dan tidak terpengaruh oleh kepentingan sepihak serta bebas dari benturan kepentingan (conflict of interest). B ank dalam mengambil keputusan harus obyektif dan bebas dari segala tekanan dan pihak manapun.

e. Kewajaran (Fairness)

Bank harus senantiasa memperhatikan kepentingan seluruh stakeholders berdasarkan azas kesetaraan dan kewajaran (equal treatment). Bank harus memberikan kesempatan kepada seluruh stakeholders untuk memberikan masukan dan menyampaikan pendapat bagi kepentingan bank serta mempunyai akses terhadap informasi sesuai dengan prinsip keterbukaan.

\section{Syariah Compliance}

Bank syariah berkewajiban menerapkan prinsip syariah dalam seluruh aktivitas kegiatan usahanya. K eharusan ini dilatarbelakngi karena adanya keinginan umat Islam akan adanya sebuah bank yang dijalankan dengan prinsip syariah. Sebagaimana dalam UndangUndang tentang Perbankan Syariah N omor 21 tahun 2008 menjelaskan bahwa prinsip syariah dalam perbankan syariah adalah prinsip hukum Islam dalam kegiatan perbankan berdasarkan fatwa yang dikeluarkan oleh DSN -MUI. ${ }^{9}$

Syariah compliance adalah bentuk ketaatan bank syariah dalam memenuhi prinsipprinsip syariah dalam operasionalnya. ${ }^{10}$ Bank syariah merupakan lembaga keuangan yang beroperasi sesuai dengan prinsip-prinsip syariah, sehingga dalam beroperasinya harus mengikuti ketentuan-ketentuan syariah khususnya menyangkut tata cara bermuamalat secara Islam. Prinsip tersebut harus diterapkan pada akad-akad yang digunakan dalam produkproduk bank syariah.

\footnotetext{
${ }^{9}$ Undang-Undang No.21/2008 Tentang Perbankan Syariah, Pasal 1 No. 12

${ }^{10}$ Siti Maria Wardayati, "Implikasi Shariah Governance Terhadap Reputasi dan Kepercayaan Bank Syariah" dalam Jurnal Walisongo, Vol. 19 No. 1 Mei 2011, 8
} 


\section{Penerapan Syariah Compliance di B ank Syariah}

Bank syariah telah memenuhi kepatuhan pada prinsip-prinsip syariah (syariah compliance) apabila dalam semua transaksi dan kegiatan usahanya tidak mengandung unsur riba, gharar dan maisir, menjalankan bisnis yang berbasis pada keuntungan yang halal, menjalankan amanah yang dipercayakan nasabah kepada bank dan mengelola zakat, infaq dan shadaqah dengan amanah. ${ }^{11}$ Penjelasan dari pemenuhan prinsip syariah di bank syariah adalah seperti di bawah ini:

a. Tidak ada riba dalam transaksi bank

Riba secara bahasa artinya adalah tambahan. Arti lain dari riba secara bahasa adalah tumbuh dan membesar. Pengertian riba secara istilah menurut A I-Jurjani adalah kelebihan atau tambahan pembayaran tanpa adanya ganti atau imbalan yang disyaratkan bagi salah satu dari dua pihak yang membuat akad atau transaksi. Sedangkan menurut A I-A ini, riba adalah penambahan atas harta pokok tanpa adanya akad atau transaksi jual beli yang riil. Pengertian riba yang lain dikemukakan oleh Qal'aji dan Qunaibi, menurut mereka riba adalah tambahan yang dipersyaratkan dalam suatu akad tanpa adanya ganti yang dibenarkan oleh syara'. ${ }^{12}$

Di dalam pengelolaan perbankan syariah harus dipastikan tidak ada transaksi yang mengandung riba. Hal tersebut merupakan pokok prinsip keuangan Islam yang tidak boleh dilanggar. Untuk itu, perbankan Islam "menjual" produk-produk pokok jual beli (murabahah) dan invesatasi (mudharabah dan musyarakah), sewa (ijaraoh).

Namun demikian, dalam praktiknya masyarakat masih menganggap ada kesamaan antara produk perbankan syariah dengan produk perbankan konvensional. Masyarakat menganggap perbankan syariah menggunakan bunga, di mana bunga menurut kesepakatan ulama termasuk riba.

Untuk menjaga operasional perbankan syariah agar tetap mengikuti prinsip tidak riba, dan memberikan kepercayaan kepada masyarakat bahwa perbankan syariah tidak sama dengan operasional perbankan konvensional, maka di dalam perbankan syariah perlu ada organ yang berfungsi memastikan transaksi-transaksi/akad-akadnya bebas riba. A dapun tugas tersebut dilakukan oleh Dewan Pengawas Syariah (DPS) sebagaimana diatur dalam peraturan OJK.

Hasil pengawasan harus diinformasikan kepada nasabah maupun ke masyarakat, agar kepercayaan masyarakat terhadap perbankan syariah semakin kuat, sekaligus mendidik masyarakat perbankan syariah bebas riba.

b. Tidak ada gharar dalam transaksi bank

Gharar adalah sesuatu yang memperdayakan manusia di dalam bentuk harta, kemegahan, jabatan, syahwat (keinginan) dan lainnya. ${ }^{13}$ G harar adalah situasi di mana terjadi incomplete information karena adanya uncertainty to both parties

\footnotetext{
${ }^{11}$ Ibid., 11-12

${ }^{12}$ Akhmad Faozan, "Implementasi Shariah Governance di Bank Syariah, dalam Jurnal Ilmu Syariah dan Hukum, Vol. 49, No. 2, Desember 2015, 349

${ }^{13}$ Andri Soemitro, Bank Dan Lembaga Keuangan Syariah Cetakan Pertama (Jakarta: Kencana Prenadamedia Group, 2009), 37
} 
(ketidakpastian dari kedua belah pihak). Di sini, baik pihak A maupun pihak B samasama tidak memiliki ketidakpastian mengenai suatu yang ditransaksikan (uncertain to both parties). Gharar terjadi bila sesuatu yang sifatnya pasti (certain) menjadi tidak pasti (uncertain). ${ }^{14}$

Gharar dapat terjadi di bank syariah dalam transaksi yang berbasis jual beli berdasarkan akad murabahah dan berbasis bagi hasil berdasarkan akad musyarakah dan mudarabah. Dalam murabahah, penentuan harga jual barang tidak boleh mempertimbangkan nilai waktu uang (time value of money).

c. Tidak ada maisir dalam transaksi bank

Maisir atau perjudian adalah suatu permainan yang menjadikan salah satu pihak menanggung beban pihak lain akibat permainan tersebut. Setiap permainan atau pertandingan harus menghindari terjadinya zero sum game, yaitu keadaan yang menjadikan salah satu pihak harus menanggung beban pihak yang lain. ${ }^{15}$

Perbankan syariah dalam akad mudharabah dan musyarakah, nasabah harus membuat laporan pendapatan usahanya untuk kemudian diserahkan kepada bank syariah sebagai shahibul mal. Laporan pendapatan tersebut semestinya menjadi pertimbangan pembagian keuntungan antara nasabah dan bank syariah yang telah disepakati pada waktu akad. Ini bertujuan sebagai pencegahan dari kemungkinan terjadinya maisir di bank syariah.

Walaupun demikian perbankan syariah telah berupaya untuk memberikan informasi bagi hasil yang diterima oleh nasabah melalui website, buku tabungan, annual report maupun informasi lainnya. A kan tetap perbankan syariah belum memberikan informasi tentang bisnis yang dijalankannya secara detail dan menyeluruh, seperti perbankan syariah sedang melakukan akad mudharabah dalam sektor apa. Walaupun di akad telah dibuat klausul tentang penyerahan penggunaan dana nasabah untuk dipergunakan perbankan syariah menjalankan bisnisnya.

Menyikapi kondisi tersebut perbankan syariah lebih membuka diri, dengan memberikan informasi yang lebih detail, misalnya tentang pembiayaan mudharabah yang sedang dilakukannya.

d. B ank menjalankan bisnis berbasis pada keuntungan yang halal

Halal secara bahasa berarti diperbolehkan oleh syara' atau kebalikan dari haram. Perbankan sebagai lembaga keuangan yang melekat kepadanya nama syariah sudah semestinya dalam operasionalnya mengikuti ketentuan-ketentuan syariah atau prinsipprinsip syariah. Prinsip tersebut adalah prinsip hukum Islam dalam kegiatan perbankan berdasarkan fatwa yang dikeluarkan oleh Dewan Syariah Nasional Majelis Ulama Indonesia (DSN-MUI). ${ }^{16}$ Bank syariah harus menerapkan prinsip-prinsip tersebut sehingga dapat menjalankan bisnis berbasis pada keuntungan yang halal.

Pihak yang mengawasi penerapan prinsip tersebut adalah Dewan Pengawas

\footnotetext{
${ }^{14}$ Adiwarman A. Karim, Bank Analisis Fiqh dan Keuangan, Edisi Tiga (Jakarta: PT Raja Grafindo Persada, 2007), 132

${ }^{15}$ Ibid., 43

${ }^{16}$ Akhmad Faozan, "Implementasi Shariah Governance .....", 350
} 
Syariah (DPS). DPS berperan dalam mengawal dan memastikan bank syariah menjalankan bisnis pada keuntungan yang halal. A pabila terdapat suatu transaksi yang diragukan kehalalannya, maka manajemen bank syariah meminta pendapat kepada DPS. DPS kemudian melakukan rapat untuk membahas dan memutuskan status hukum transaksi tersebut. Dalam hal ini bank syariah wajib mengikuti pendapat yang dikeluarkan oleh DPS.

e. Bank mengelola zakat, infaq dan shadaqah sesuai ketentuan syar' i

Zakat adalah istilah al-Quran yang menandakan kewajiban khusus memberikan sebagian kekayaan individu dan harta untuk amal. secara harfiah zakat berasal dari akar kata dalam bahasa arab yang berarti "memurnikan" dan "menumbuhkan". ${ }^{17}$ Salah satu di antara yang membedakan antara bank syariah dengan bank konvensional adalah kewajibannya untuk mengelola zakat. Bentuk kewajiban tersebut adalah dengan membayar zakat, menghimpun zakat, mencatatnya dalam sistem administrasi yang baik dan mendistribusikannya. Selain mengelola zakat, bank syariah pun wajib mengelola infak dan sedekah. Ini merupakan fungsi dan peran yang melekat pada bank syariah untuk memobilisasi dana-dana sosial. ${ }^{18}$

\section{Implementasi Syariah G overnance pada B ank Syariah}

Di awal telah disebutkan bahwa syariah governance adalah penerapan gabungan antara konsep Good Corporate Governance (GCG) dengan syariah compliance. Syariah complaince yang pada dasarnya bertumpukan kepada transparancy, responbility, accountability, fairness, independency, tidak riba, tidak gharar, tidak maisir, halal yang merupakan hal yang seharusnya dilakukan sehingga merupakan budaya kerja yang islami, sebagaimana dikemukakan oleh Umar Chapra bahwa stakeholders utama keuangan Islam adalah Islam itu sendiri. ${ }^{19}$

Dengan demikian, bank syariah dituntut untuk melakukan kinerja yang baik sebagai cerminan dari kegiatan yang islami. Dalam Islam, terdapat beberapa konsep yang relevan dengan GCG, yaitu idarah (pengelolaan), khilafah (kepemimpinan), aqidah (keimanan), akhlaq (moral), ijabiyah (berfikir positif), hurriyah (independensi dan kebebasan yang bertanggungjawab), 'adalah (keadilan), tawazun (keseimbangan), mas'uliyah (akuntabilitas), raqabah (pengawasan), qira'ah dan ishlah (organisasi yang terus belajar), amanah (pemenuhan kepercayaan), shiddiq (jujur), fathanah (pengembangan diri untuk cerdas), tabligh (keterbukaan), ihsan (profesional) dan wasatha (kewajaran). ${ }^{20}$

Governance pada institusi bank syariah memiliki keunikan tersendiri dibandingkan dengan governance pada perusahaan non-bank syariah. Hal ini terutama disebabkan oleh kehadiran deposan sebagai suatu kelompok stakehoholders yang kepentingannya harus diakomodasi dan dijaga. Namun, keberadaan kelompok deposan pada perbankan

\footnotetext{
${ }^{17}$ Nurul Huda, Zakat Perspektif Mikro-Makro: Pendekatan Riset Edisi Pertama (Jakarta: Prenamedia Group, 2015), 1

${ }^{18}$ Akhmad Faozan, "Implementasi Shariah Governance .....", 351

${ }^{19}$ Dhani Gunawan Idat, "Perbankan Syariah Menghadapi 2005-2008", dalam www.e-syariah.com, (12 Maret 2016)

${ }^{20} \mathrm{Ibid}$
} 
konvensional tidak terlalu banyak mempengaruhi struktur governance bank. Alasannya adalah: pertama, secara akad bank telah menetapkan jaminan untuk membayar penuh simpanan nasabah; kedua, penerapan skema penjaminan baik oleh lembaga penjamin simpanan maupun pemerintah; dan ketiga, penerapan secara ketat sejumlah ramburambu dalam bentuk ketentuan kehati-hatian perbankan oleh otoritas pengawasan perbankan. Faktor-faktor inilah yang melindungi kepentingan nasabah deposan terhadap kepentingan stakeholder lainnya dalam bank, sehingga mengurangi desakan perlunya struktur governance yang khusus untuk melindungi para deposan bank. Sementara bagi bank syariah, baik pemegang saham maupun pemilik rekening (investment account holders) merupakan pihak yang sama-sama dijamin keberadaannya dan perlu diakomodasi keberadaannya.

\section{Pengawasan Penerapan Syariah G overnance pada B ank Syariah}

Implementasi syariah governance pada bank syariah bertumpu pada pengawasan yang meliputi segala kegiatan penelitian, pengamatan, dan pengukuran terhadap jalannya operasi berdasarkan rencana yang telah ditetapkan, penafsiran dan perbandingan hasil yang dicapai dengan standar yang diminta, melakukan tindakan koreksi penyimpangan, dan perbandingan antara hasil (output) yang dicapai dengan masukan (input) yang digunakan. ${ }^{21}$

Dari pengertian di atas, maka menurut prosesnya, pengawasan meliputi kegiatankegiatan sebagai berikut:

1. M enentukkan standar sebagai ukuran pengawasan.

2. Pengukuran dan pengamatan terhadap jalannya operasi berdasarkan rencana yang telah ditetapkan.

3. Penafsiran dan perbandingan hasil yang dicapai dengan standar yang diminta.

4. M elakukan tindakan koreksi terhadap penyimpangan.

5. Perbandingan hasil akhir (output) dengan masukan (input) yang digunakan.

Peran pengawasan bank adalah memastikan apakah bank memliki kebijakan, prosedur, dan pedoman penilaian kredit, serta menguji konsistensi pelaksanaannya. Pengawasan bank syariah pada dasarnya memiliki dua sistem, yaitu sistem pengawasan internal, yang memiliki unsur-unsur: RUPS, Dewan Komisaris, Dewan Audit, Dewan Pengawas Syariah (DPS), Direktur Kepatuhan, SKAI-Internal Syariah Reviewer dan sistem pengawasan eksternal terdiri dari unsur Otoritas J asa K euangan (OJK), A kuntan Publik, Dewan Syariah Nasional (DSN) dan Stakeholders/masyarakat pengguna jasa. Secara umum, peran dan tanggung jawab OJK lebih kepada pengawasan aspek keuangan, sedangkan jaminan pemenuhan prinsip syariah adalah tanggung jawab dan kewenangan DSN dengan DPS. ${ }^{22}$

M ekanisme pengawasan DPS terhadap bank syariah yaitu dengan mengadakan analisis operasional bank syariah dan mengadakan penilaian kegiatan maupun produk dari bank tersebut yang pada akhirnya dewan pengawas syariah dapat memastikan bahwa kegiatan

${ }^{21}$ Zainul Arifin, Dasar-Dasar Manajemen Bank Syariah, Edisis Revisi, Cet. 7 (Jakarta: Azkia Publisher, 2009), 135

22 Harisman, "Pelaksanaan Pengawasan Perbankan Syariah Di Indonesia" dalam www.pemikirangadogado.blogspot.com/2010/10/pelaksanaan- pengawasan-perbankan.html., (12 Maret 2016) 
operasional bank syariah telah sesuai dengan fatwa yang dikeluarkan oleh DSN, memberikan opini dari aspek syariah terhadap pelaksanaan operasional bank dan produk yang dikeluarkan, mengkaji produk dan jasa baru yang belum ada fatwanya, dan akhirnya menyampaikan laporan hasil pengawasan syariah sekurang- kurangnya 6 (enam) bulan sekali kepada direksi, komisaris, DSN dan 0JK. ${ }^{23}$

Dengan demikian, mekanisme pengawasan bank syariah memiliki dua unsur, yaitu pengawasan internal yang terdiri dari RUPS, Dewan Komisaris, Dewan Audit, Dewan Pengawas Syariah (DPS), Direktur Kepatuhan, SKAI- Internal Syariah Reviewer dan pengawasan eksternal yang terdiri dari unsur OJK A kuntan Publik, Dewan Syariah Nasional (DSN) dan Stakeholders/masyarakat pengguna jasa. Kedua unsur ini bertujuan memastikan apakah bank memliki kebijakan, prosedur, dan pedoman penilaian kredit, serta menguji konsistensi pelaksanaannya.

\section{Dewan Komisaris}

Pengertian dewan komisaris adalah organ perseroan yang bertugas melakukan pengawasan secara umum dan/atau khusus sesuai dengan anggaran dasar serta memberi nasihat kepada direksi. Dewan komisaris memegang peranan penting dalam implementasi good corporate governance sebagai salah satu bagian dari syariah governance, karena dewan komisaris merupakan inti dari good corporate governance yang bertugas untuk menjamin pelaksanaan strategi perusahaan, mengawasi manajemen dalam mengelola perusahaan, serta mewajibkan terlaksananya akuntabilitas. Dalam prakteknya, di Indonesia sering terjadi anggota dewan komisaris sama sekali tidak menjalankan peran pengawasannya yang sangat dasar terhadap dewan direksi. Dewan komisaris seringkali tidak dianggap dan tidak memiliki manfaat, hal ini dapat dilihat dalam fakta bahwa banyak anggota dewan komisaris tidak memiliki kemampuan dan tidak menunjukkan indepedensinya.

Secara hukum, dewan komisaris bertugas melakukan pengawasan dan memberikan nasehat kepada direksi. Dewan komisaris dalam melaksanakan tugasnya harus mampu menguasai dipenuhinya kepentingan semua stakeholders berdasarkan atas kesetaraan. Bagi bank sebagai lembaga intermediasi dan lembaga kepercayaan yang highly regulated. Jadi, tugas dan fungsi dewan komisaris yaitu:

a. Dewan komisaris wajib melaksanakan tugas dan tanggung jawab sesuai dengan prinsip GCG.

b. Dewan komisaris wajib melakukan pengawasan atas terselenggaranya pelaksanaan GCG dalam setiap kegiatan usaha BUS pada seluruh tingkatan atau jenjang organisasi.

c. Dewan komisaris wajib melaksanakan pengawasan terhadap pelaksanaan tugas dan tanggung jawab direksi, serta memberikan nasihat kepada direksi.

d. Dewan komisaris bertanggung jawab terhadap terlaksananya tugas secara efektif dan efisien serta terpeliharanya efektifitas komunikasi antara dewan komisaris dengan direksi, auditor eksternal dan Otoritas Pengawasan B ank

\footnotetext{
${ }^{23}$ Sri Dewi Anggadini. "Mekanisme Pengawasan Dewan Pengawas Syariah dan Bank Indonesia Terhadap Bank Syariah", dalam Jurnal Majalah Ilmiah Unicom, Volume XII, Nomor 1 (2014)
} 
e. Dewan komisaris berkewajiban melakukan tindak lanjut dari hasil pengawasan dan rekomendasi yang diberikan terutama dalam hal terjadi penyimpangan dari ketentuan perundang-undangan, anggaran dasar, dan prudential banking practices

f. Dewan komisaris wajib memiliki tata tertib kerja yang mengikat dan ditaati oleh semua anggotanya.

g. A nggota dewan komisaris bank dilarang memanfaatkan bank untuk kepentingan pribadi, keluarga, perusahaan atau kelompok usahanya dengan semangat dan cara yang bertentangan dengan peraturan perundang-undangan dan kewajaran di bidang perbankan.

h. Dewan komisaris dilarang terlibat dalam pengambilan keputusan kegiatan operasional BUS, kecuali pengambilan keputusan untuk pemberian pembiayaan kepada direksi sepanjang kewenangan dewan komisaris tersebut ditetapkan dalam anggaran dasar BUS atau dalam Rapat U mum Pemegang Saham.

i. Anggota dewan komisaris secara hukum bertanggung jawab kepada bank, dengan ketentuan Undang-Undang Perseroan Terbatas atau Undang-Undang yang berlaku bagi pendirian bank bersangkutan, U ndang-U ndang Perbankan dan A nggaran D asar B ank.

j. Anggota dewan komisaris wajib menyediakan waktu yang cukup untuk melaksanakan tugas dan tanggung jawabnya secara optimal.

Jadi, dapat disimpulkan bahwa dewan komisaris adalah organ perusahaan yang bertugas dan bertanggung jawab secara kolektif untuk melakukan pengawasan dan memberikan nasihat kepada direksi serta memastikan sebuah bank melaksanakan GCG pada seluruh tingkatan dan jenjang organisasi.

\section{Dewan Direksi}

Pengertian dewan direksi adalah organ perseroan yang berwenang dan bertanggung jawab penuh atas pengurusan perseroan untuk kepentingan perseroan sesuai dengan maksud dan tujuan perseroan serta mewakili perseroan, baik di dalam dan di luar pengadilan sesuai dengan ketentuan anggaran dasar.

Direksi sebagai organ perusahaan bertugas dan bertanggung jawab secara kolegal dalam mengelola perusahaan. M asing-masing anggota direksi dapat melaksanakan tugas dan mengambil keputusan sesuai dengan pembagian tugas oleh masing-masing anggota direksi tetap merupakan tanggung jawab bersama. Kedudukan masing-masing anggota direksi termasuk direktur utama adalah setara. Dengan demikian, tugas dan fungsi dewan direksi adalah sebagai berikut:

a. Direksi bertanggung jawab penuh atas pelaksanaan pengelolaan BUS berdasarkan prinsip kehati-hatian dan prinsip syariah.

b. Direksi wajib mengelola BUS sesuai dengan kewenangan dan tanggung jawabnya sebagaimana diatur dalam A nggaran dasar BUS dan perundang- undangan yang berlaku.

c. Direksi wajib menindaklanjuti temuan audit dan/atau rekomendasi dari hasil pengawasan Bank Indonesia, auditor intern, DPS dan/atau audit ekstern.

d. Direksi berhak dan berkewajiban untuk: (a) Melakasanakan ketentuan yang tercantum dalam anggaran dasar bank; (b) M engimplementasikan visi, misi, strategi, sasaran usaha serta rencana jangka panjang dan jangka pendek; (c) M enjalankan prinsip perbankan 
yang sehat, termasuk namun tidak terbatas pada manajemen risiko dan sistem pengendalian internal (internal control system).

e. Direksi harus memiliki tata tertib kerja yang mengikat dan ditaati oleh semua anggotanya.

Jadi, dapat disimpulkan bahwa dewan direksi adalah organ perseroan yang berwenang dan bertanggung jawab penuh atas pengurusan perseroan untuk kepentingan perseroan sesuai dengan maksud dan tujuan perseroan serta mewakili perseroan, baik di dalam dan di luar pengadilan sesuai dengan ketentuan anggaran dasar.

\section{Komite-K omite}

Sebagai bagian dari implementasi prinsip-prinsip Good Corporate Governance, dewan komisaris telah membentuk komite audit, komite pemantau risiko serta komite remunerasi dan nominasi dalam rangka mendukung efektifitas pelaksanaan tugas dan tanggung jawab dewan komisaris. Komite audit dan komite pemantau risiko diketuai oleh seorang komisaris independensi dan 2 (dua) orang anggota komite yang berasal dari pihak independensi. $\mathrm{K}$ eberadaan komisaris independensi dan pihak independen agar tercipta check and balance.

a. Komite A udit

1) Komite Audit bertugas membantu dewan komisaris untuk memastikan bahwa: (a) laporan keuangan disajikan secara wajar sesuai dengan prinsip akuntansi yang berlaku umum, (b) struktur pengendalian internal perusahaan dilaksanakan dengan baik, (c) pelaksanaan audit internal maupun eksternal dilaksanakan sesuai dengan standar audit yang berlaku, dan (d) tindak lanjut temuan hasil audit dilaksanakan oleh manajemen;

2) Komite audit memproses calon auditor eksternal termasuk imbalan jasanya untuk disampaikan kepada dewan komisaris;

3) Jumlah anggota komite audit harus disesuaikan dengan kompleksitas perusahaan dengan tetap memperhatikkan efektifitas dalam pengambilan keputusan.

b. Komite Nominasi dan R emunerasi

Komite nominasi dan remunerasi bertugas membantu dewan komisaris dalam menetapkan kriteria emilihan calon anggota dewan komisaris dan direksi serta sistem remunerasinya. Komite nominasi dan remunerasi bertugas membantu dewan komisaris mempersiapkan calon anggota dewan komisaris dan direksi dan mengusulkan besaran remunerasinya. dewan komisaris mengajukan calon tersebut dan remunerasinya untuk memperoleh keputusan RUPS dengan cara sesuai ketentuan A nggaran Dasar.

c. Komite Kebijakan Risiko

Komite kebijakan resiko bertugas membantu dewan komisaris dalam mengkaji sistem manajemen risiko yang disusun oleh direksi serta menilai toleransi risiko yang dapat diambil oleh perusahaan. Anggota komite kebijakan risiko terdiri dari anggota dewan komisaris, dan memiliki tugas dan fungsi melakukan evaluasi tentang kebijakan manajemen risiko, melakukan evaluasi tentang kesesuaian antara kebijakan manajemen risiko dengan pelaksanaan kebijakan tersebut, serta melakukan evaluasi pelaksanaan tugas komite manajemen risiko dan satuan kerja manajemen risiko. Dengan demikian 
komite audit, komite pemantau risiko serta komite remunerasi dan nominasi dibentuk dalam rangka mendukung efektifitas pelaksanaan tugas dan tanggung jawab dewan komisaris.

\section{Penutup}

Penerapan Syariah governance merupakan pelaksanaan prinsip Good Corporate Governance dan syariah complaince. Penerapan GCG pada perbankan syariah dengan menciptakan keterbukaan (transparancy) untuk mencegah terjadinya fraud, melakukan akuntabilitas (accountability) dengan sistem yang mengendalikan hubungan antara organorgan yang ada di perusahaan, melakukan tanggung jawab (responsibility), menjaga independensi (independency), menjaga hubungan dengan kewajaran (fairness).

Penerapan syariah compliance di bank Syariah tidak ada riba dalam transaksi bank, tidak ada gharar dalam transaksi bank, tidak ada maisir dalam transaksi bank, bank menjalankan bisnis berbasis pada keuntungan yang halal, bank mengelola zakat, infaq dan shadaqah sesuai ketentuan syar'i. Implementasi syariah governance pada bank syariah bertumpu pada pengawasan meliputi segala kegiatan penelitian, pengamatan, dan pengukuran terhadap jalannya operasi dengan menggunakan unsur-unsur RUPS, Dewan Komisaris, Dewan Audit, Dewan Pengawas Syariah (DPS), Direktur Kepatuhan, SKAIInternal Syariah Reviewer dan sistem pengawasan eksternal terdiri dari unsur Otoritas Jasa Keuangan (OJK), A kuntan Publik, Dewan Syariah Nasional (DSN) dan Stakeholders/masyarakat pengguna jasa.

\section{Daftar R ujukan}

A ntonio, Muhammad Syafii, Bank Syariah Dari Teori ke Praktik, Jakarta: Gema Insani Press, 2001

A rifin, Zainul, Dasar-Dasar Manajemen Bank Syariah, Edisi Revisi, Cet. 7, Jakarta: Azkia Publisher, 2009

Anggadini, Sri Dewi, “Mekanisme Pengawasan Dewan Pengawas Syariah dan Bank Indonesia Terhadap B ank Syariah" dalam J urnal M ajalah IImiah Unicom, V olume XII, Nomor 1, Tahun 2014

Daniri, M as A chmad, Good Corporate Governance: Konsep dan Penerapan dalam Konteks Indonesia, Jakarta: Triexs Triamarindo, 2005

Effendi, Muh. A rif, The Power of Good Corporate Governance: Teori dan Implementasi, Jakarta: Salemba Empat, 2009

Faozan, A khmad, A sy-Syir'ah, dalam Jurnal Ilmu Syariah dan Hukum, Vol. 49, No. 1, Desember 2014

Huda, Nurul, Zakat Perspektif Mikro-Makro: Pendekatan Riset, Edisi Pertama, Jakarta: Prenamedia group, 2015

Harisman, "Pelaksanaan Pengawasan Perbankan Syariah Di Indonesia" dalam www.pemikirangado-gado.blogspot.com/2010/10/pelaksanaan-pengawasanperbankan.html

Idat, Dhani Gunawan "Perbankan Syariah Menghadapi 2005-2008", dalam www.e- 
syariah.com (12 M aret 2016)

Keputusan M enteri Badan U saha M ilik Negara No.K ep 117 / M -M BU / 2002

Moeljono, Djokosantoso, Good Corporate Culture Sebagai Inti Dari Good Corporate Governance, J akarta: PT. Elox M edia K omputindo, 2005

Prasetyantoko, Corporate Governance; Pendekatan Institusional, Jakarta: Gramedia Pustaka Utama, 2008

Soemitro, A ndri, B ank Dan L embaga K euangan Syariah Cetakan Pertama, Jakarta: K encana Prenadamedia Group, 2009

Sutedi, A drian, Good Corporate Governance, Jakarta: Sinar Grafika, 2011

Nasution, Bismar, "Prinsip K eterbukaan dalam Good Corporate Governance" dalam Jurnal Hukum Bisnis, Volume XXII, Nomor 6, Tahun 2003

Prakarsa, Wahjudi, "Corporate Governance: Suatu Keniscayaan" dalam Jurnal Reformasi Ekonomi, Volume I, Nomor 2, (Oktober-D esember 2000)

Tjondro, David dan R. Wilopo, "Pengaruh Good Corporate Governance (GCG) Terhadap Profitabilitas Dan K inerja Saham Perusahaan Perbankan Y ang Tercatat Di Bursa Efek Indonesia" dalam J ournal of Business \& Banking, Volume I, Nomor 1, M ay 2011

Wardayati, Siti M aria, "Implikasi Shariah Governance Terhadap Reputasi dan Kepercayaan Bank Syariah" dalam J urnal Walisongo, V ol. 19 N o. 1 M ei 2011

Zarkasyi, Moh. Wahyudin, Good Corporate Governance Pada Badan Usaha Manufaktur, Perbankan, dan J asa K euangan Lainnya, cet.I, B andung: A Ifabeta, 2008

Organization for Economic Coperation and Development (OECD), The OECD Principles of Corporate Governance, 2004, dalam http://www.oecd.org 